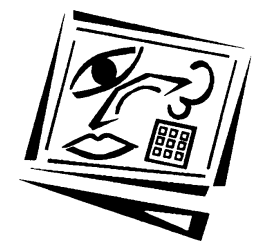

\title{
E-learning interactions, information technology self efficacy and student achievement at the University of Sharjah, UAE
}

Enas Said Abulibdeh

Al Ain University of Science and Technology, United Arab Emirates

Sharifah Sariah Syed Hassan

International Islamic University Malaysia

\begin{abstract}
The purpose for this study is to validate a model of student interactions (studentcontent, student-instructor and student-student interactions and vicarious interaction), information technology self efficacy and student achievement. Investigation of the relationships was undertaken with structural equation modeling analyses, in a study with 250 undergraduate students providing 231 responses for the final analyses. Adopting a framework from Moore (1989) and Devries (1996) on e-learning interactions and Bandura (1997) on self efficacy, this study has found that student interactions can be predictors of student achievement. However, self-efficacy can only promote student achievement via student interactions in an e-learning environment. Although the hypothesised model showed an overall fit, it was further re-specified due to non significant relationships between IT self efficacy and student achievement.
\end{abstract}

\section{Introduction}

Universities around the world are moving rapidly to introduce information and communication technologies (ICTs) into all aspects of their core business of teaching and learning (Bates, 2001; Ryan, Scott, Freeman \& Patel, 2000). In the United Arab Emirates (UAE), public and private universities are becoming more engaged with the new technologies as they strive to get international accreditation and be more competitive in the global market. The University of Sharjah (UOS) in the UAE is among one of the universities that has already embraced e-learning in teaching and learning since 2004. UOS adopted the Blackboard learning system, to enable e-learning to be delivered more effectively, and also in a cost-effective way.

Interaction is the heart of any e-learning success. Empirical research has proven that interaction is the main factor for student satisfaction and perceptions of how learning communities are built (Garrison \& Anderson, 2003; Hillman, Willis \& Gunawardena, 1994; Moore, 1989; Wagner, 1994). Recent research by Schone (2007) has introduced levels of online interactions namely; passive, limited, complex and real time. Passive interaction involves the receiver in reading and communicating with the content from the screen. The limited interaction involves some interactivities for the reader's response. The complex interaction deals with simulations and actual data that can promote student interest to persist in learning, and real time relates to interaction of learner and lecturers online. These interactions are based upon the degree of 
interactivity with the learning environment. Moore (1989) however categorised online interactions as student-student, student-instructor, student-content, and studentinterface. A further development of online interaction includes vicarious interaction (Sutton, 1996; Davries, 2001) where learners learn by observing from other students through discussion and participation. Notwithstanding the terms used to describe online interactions, the learning activities will depend on the effectiveness of the online learning design as well as efficient information technology use.

Interaction in an e-learning educational environment is different as compared to the interaction in traditional educational settings. The difference is mainly in the medium used in teaching and not with the components of interaction as both of them share similar interactions. The traditional and the e-learning environments both share student-student, student-instructor, and student-content interactions.

The use of online technologies in education can take many forms and can assume many different roles in an educational setting. Harmon and Jones (1999) have described five levels of web use in schools, colleges and corporate training: (a) informational, (b) supplemental, (c) essential, (d) communal and (e) immersive. Each level represents the relative amount of online related course content and the level of reliance on the course website to deliver instruction. According to Ryan (2001), elearning can be implemented in a variety of ways such as through the use of self-paced independent study units, in asynchronous interactive sessions (where participants interact at different times) or synchronous interactive settings (where learners meet in real time). In practice, Devries (2005) has noticed that e-learning tends to open up opportunities for informal learning using online content developed for formal elearning. On the other hand, the use of e-learning in formal education has added flexibility to teaching and learning processes, offering opportunities for informal learning behaviour.

In this present study, the framework is based on Moore's (1989) online interactions, namely student-content, student-instructor, and student-student interactions. Studentstudent interaction includes contact with other students via synchronous or asynchronous technologies, such as email, class discussion board, group work, social networks, projects, Groove, blogs, wikis and podcasts. Researchers have shown that giving adequate opportunities to participate in online discussions leads participants to be associated with enhanced social presence (Gunawardena, Lowe \& Anderson, 1997). Student-instructor interaction can be either synchronous or asynchronous, by using technology tools such as chats, whiteboard sessions, email, phone calls, blogs, wikis and podcasts. These technologies could provide a learning environment that may allow interactions with or without the physical presence of the student and instructor.

Student-content interaction involves pedagogical tools and assignments which include computer technology tools such as PowerPoint presentations, streaming audio and video presentation or individual projects such as embedded links that can be linked to Internet or other resources. These technology tools and activities can provide a social constructivist environment in which students become knowledge creators (BenbunanFich, 2002), and can include communicating of course navigation, style, look and feel (Hillman, Willis \& Gunawardena, 1994). In other words, all communication and interactions become mediated by the interface with which students must interact each time they wish to perform some task in the computer-mediated environment. The last type of interaction is vicarious interaction which Devries (1996), has described as 
students participating internally and silently responding to questions. Sutton (2001), has explained that vicarious interaction could often happen when a student chose to observe rather than actively participate in online discussions and debates. Therefore, this form of interaction was very intrinsic and thus difficult to observe, because students who become involved with the thoughts and ideas will not necessarily respond to them. Thus, the vicarious interaction has not been utilised in the present research.

Several studies have examined the relationships between IT self-efficacy and a variety of computer behaviours (Burkhardt \& Brass, 1990; Webster \& Martocchio, 1992; Marakas, Yi \& Johnson, 1998). In order to be motivated and be successful in an elearning setting, students should possess two types of IT self-efficacy. Firstly, students should have a liking towards the course content and secondly, students should feel efficacious in using e-learning components to communicate with instructors, content and classmates. Based on the framework discussed, the present study has been designed to investigate the relationships between the e-learning components of interactions; student-student, student-instructor and student-content interaction, and IT self-efficacy with regards to students' academic achievement.

\section{Methods}

\section{Sampling and instrument design}

Data for this research was obtained from three sources. These are students' final grades, a collection of digital documents from the courses offered through the Blackboard system and its digital logs, and finally a survey using a modified IT selfefficacy instrument created by Miltiadou and Yu (2000).

For the log entry, the cooperating lecturers agreed to provide access to their log files after finishing the conduct of their courses. This provided information on the frequency of use of interactions in the e-learning environment, as well the students' achievement of grades and accumulative total averages (ACGP).

Interactions were measured from the frequency of use different applications such as Address Book, Announcements, Dictionary / Thesaurus, Glossary, Blackboard Scholar, Scholar Course Home, My Scholar Home, Calendar, Chalk Title Management, Collaboration, Content Area, Communications Area, E-mail, Tools Area, Discussion Board, Dropbox, Homepage, Early Warning System, Groups, Gradebook, Manual, Messages, Observer Tools, Performance Dashboard, Personal Information, Staff Information, My Grades and Tasks as stated in the Blackboard System Manual (2007).

The total population size in this study consisted of 6,269 undergraduates. However, only 2000 students enrolled in courses were using the Blackboard system. For the purpose of this study, 250 students who were enrolled in the general university requirement courses at the first semester 2007/2008 were selected from the target population of 2000. However, at the end of the semester, 19 students either dropped out or did not attend classes. As a result 231 students remained in the final study.

The research adapted 17 items (5 point Likert scale, strongly agree to strongly diasagree) from the instrument Online Technologies Self-efficacy Scale (OTSES) developed by Miltiadou and Yu (2000), based on the specific features of the Blackboard system. 
Another 20 self constructed items were designed to reveal information on frequency of student-student, student-content and student-instructor interactions. The student achievement results were obtained from the demographic data. For each item, students were asked to indicate the frequency of use or "visits" on a five point scale (Table 1).

Table 1: Scale of instrument for online interaction

\begin{tabular}{|c|c|}
\hline Scale & Frequency of use \\
\hline 1 & $1-3$ \\
\hline 2 & $4-7$ \\
\hline 3 & $8-11$ \\
\hline 4 & $12-15$ \\
\hline 5 & 16 and above \\
\hline
\end{tabular}

The instrument was administered in English language as the learning was conducted in English. The instrument was subjected to three steps in validation, namely face, content and construct validity. Face and content validation included consulting with three lecturers for appropriate usage of language and content, and also trial questionnaires distributed to five students. The construct validity included a pilot study from a total of 205 students at the bachelor's degree level from different courses (English 1, English 3 and Introduction to IT). The reliability of the pilot instrument was found to be highly reliable with Cronbach's alpha 0.80 .

\section{Results}

\section{Breakdown of students based on gender and faculties or Kulliyah}

A total of 231 students participated in this study with 158 females and 73 males involved in six different faculties or Kulliyahs. $71 \%$ (65) of the faculty of Engineering students were females (Table 2).

Table 2: Gender of students and Kulliyah

\begin{tabular}{|l|c|c|c|c|c|c|c|}
\hline \multirow{2}{*}{ Gender } & \multicolumn{6}{|c|}{ Kulliyah/Faculty } & \multirow{2}{*}{ Total } \\
\cline { 2 - 7 } & $\begin{array}{c}\text { Arts and Social } \\
\text { Sciences }\end{array}$ & $\begin{array}{c}\text { Engin- } \\
\text { eering }\end{array}$ & $\begin{array}{c}\text { Commun- } \\
\text { ication }\end{array}$ & $\begin{array}{c}\text { Economics } \\
\text { and Business }\end{array}$ & Other & $\begin{array}{c}\text { Syariah } \\
\text { (Islamic Law) }\end{array}$ & \\
\hline Male & 0 & 26 & 7 & 9 & 2 & 29 & 73 \\
\hline Female & 24 & 65 & 25 & 17 & 16 & 11 & 158 \\
\hline Total & 24 & 91 & 32 & 26 & 18 & 40 & 231 \\
\hline
\end{tabular}

\section{Student achievement and interactions category distributions retrieved from the log files of the Blackboard system}

Table 3 shows the distribution of achievement variables with the mean score and the standard deviation. The mean score of accumulative grade point average or ACGPA (2.6) and cumulative grade point average or CGPA (2.8) indicate that students have achievement above the average mean score $(>2.5)$. The standard deviations for both ACGPA and CGPA were high revealing a good dispersion of data.

Table 3: Distribution of the achievement variables

\begin{tabular}{|l|c|c|c|c|}
\hline & Mean & Std dev & Skewness & Kurtosis \\
\hline ACGPA & 2.586 & 0.8921 & -.293 & -.317 \\
\hline CGPA & 2.786 & 1.074 & -.498 & -.973 \\
\hline
\end{tabular}




\section{Validating the hypothesised structural model of e-learning interactions and student achievement}

Upon the deletion of items to estimate the model fit, the results of the structural model reveal the model adequacy with referral fit indices given in Table 4.

Table 4: Results of goodness of fit indices of the hypothesised structural model

\begin{tabular}{|l|c|c|c|c|c|c|c|}
\hline \multicolumn{1}{|c|}{ Goodness of fit indices } & $\chi^{2}$ & $\mathrm{df}$ & $\chi^{2} / \mathrm{df}$ & $\mathrm{p}$ & CFI & TLI & RMSEA \\
\hline Recommended value & - & - & $<3.0$ & $>.001$ & $>.90$ & .90 & $<.08$ \\
\hline Hypothesised model & 84 & 51 & 1.65 & .002 & .98 & .97 & .053 \\
\hline
\end{tabular}

The hypotheses indicating the relationships of the hypothesised e-learning interaction model were estimated as follows:

H1: Students' e-learning interaction activities significantly influence students' academic achievement.

H2: Students' perceived IT self-efficacy significantly influence students' academic achievement.

H3: Students' perceived IT self-efficacy significantly influences students' elearning interaction activities.

H4: Students' perceived IT self-efficacy significantly influences students' achievement via students' e-learning interaction activities.

Figure 1 reveals the hypothesised structural model with standardised parameter estimates. Table 5 shows the summary of the direct and indirect effects.

Table 5: Summary of standardised direct effect between parameters

\begin{tabular}{|l|l|c|c|c|}
\hline & \multicolumn{2}{|c|}{ Parameters } & $\begin{array}{c}\text { Standardised } \\
\text { estimate }\end{array}$ & $\begin{array}{c}\text { Critical } \\
\text { ratio (CR) }\end{array}$ \\
\hline \multirow{2}{*}{ Direct effect } & e-learning interaction $\rightarrow$ Achievement & 0.67 & 5.63 \\
\cline { 2 - 6 } & IT self-efficacy $\rightarrow$ Achievement (not sig) & 0.10 & .87 \\
\cline { 2 - 6 } & IT self-efficacy $\rightarrow \quad$ e-learning interaction & 0.82 & 9.654 \\
\hline Indirect effect & IT self-efficacy $\rightarrow$ & e-learning $\rightarrow$ Achievement & 0.55 & \\
\hline
\end{tabular}

Notes for Table 5: The factor loading for e-learning interaction $\leftarrow$ IT self-efficacy was significant at $0.01(\mathrm{CR}>1.96)$. The direct effect was significant for e-learning $\rightarrow$ Achievement at $0.01(\mathrm{CR}>1.96)$, the direct effect was not significant for IT selfefficacy $\rightarrow$ achievement at $0.01(\mathrm{CR}<1.96)$, the indirect effect of IT self-efficacy $\rightarrow$ elearning $\rightarrow$ Achievement was not significant.

The results have shown that IT self efficacy did not significantly influence students' achievement with a standardised direct effect of 0.10 (CR $<1.96)$. Thus, the second hypothesis (H2: Students' perceived IT self efficacy significantly influences students' academic achievement) has been rejected despite other relationships being significant. Therefore, the model has been revised with the relationship of IT self efficacy and achievement has been removed. The results of the revised model have shown improvements with $\chi^{2}(\mathrm{df}=52)=84.7, p=0.003, \mathrm{CMIN} / \mathrm{df}=1.63$, TLI $=0.97, \mathrm{RMSEA}=$ 0.052 , and $\mathrm{CFI}=0.98$. All the standardised factor loadings were high, ranging from 0.49 to 0.90 with error variances in the acceptable range $(<0.9)$. The revised model reveals only $59 \%$ of variance explained where student achievement was predicted by self efficacy via e-learning interactions. This indicates that other factors may contribute to the model and further research need to be carried out. 


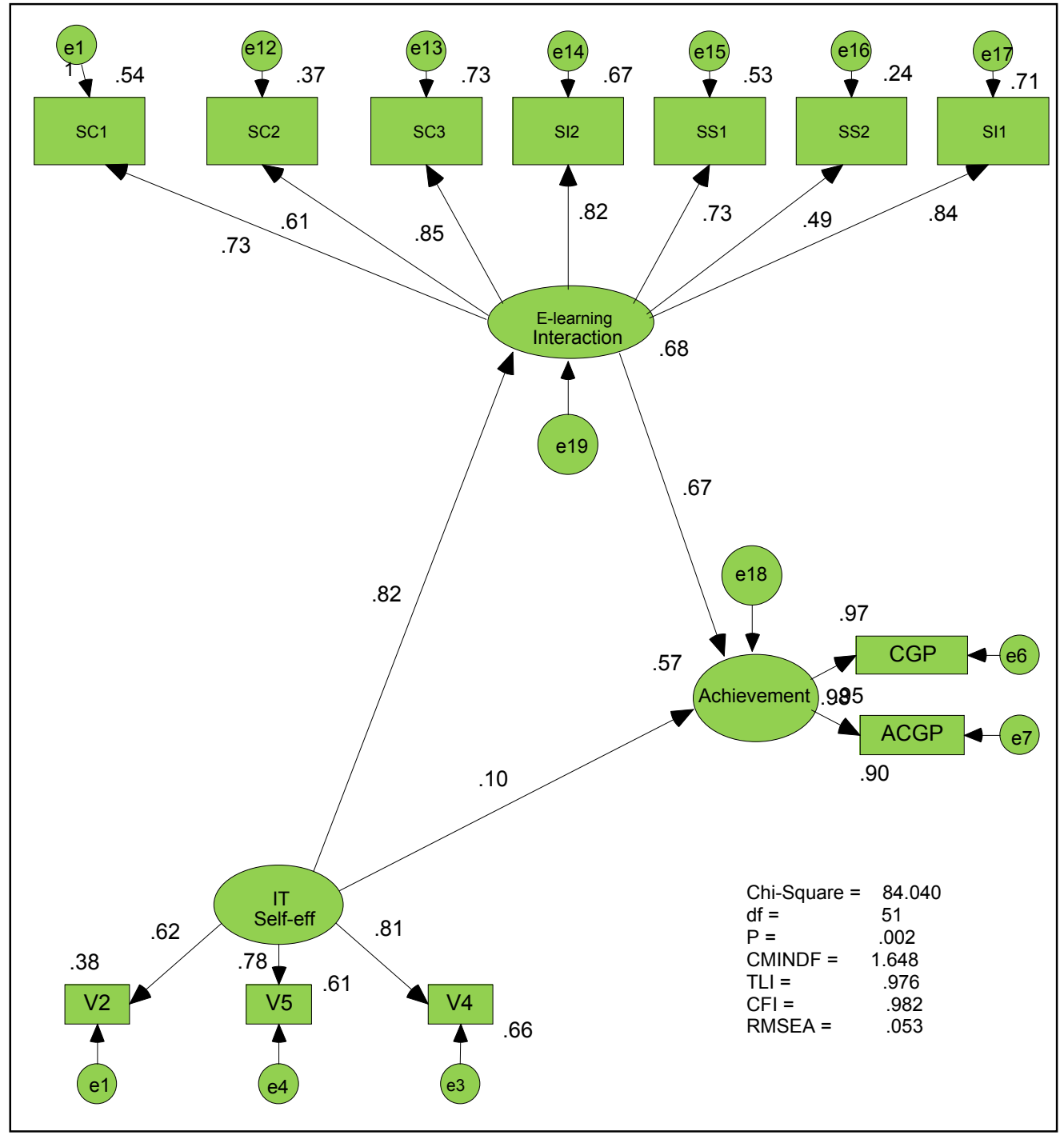

Figure 1: The hypothesised e-learning interaction model Note: The model was rejected due to non-significant path of IT self efficacy and achievement. The model has been revised with the non-significant path deleted.

Table 6 reveals the standardised parameter estimates of the items selected for the revised model.

\section{Discussion and implications}

The results revealed a significant relationship between students' IT self-efficacy and students' academic achievement through the influence of e-learning interactions. Therefore, students' IT self-efficacy could only predict students' academic achievement if they were involved in the e-learning interaction activities. 
Table 6: Maximum likelihood parameter estimates for revised e-learning interaction model

\begin{tabular}{|c|c|c|c|c|c|}
\hline & \multirow[b]{2}{*}{$\mid \begin{array}{c}\text { Factor } \\
\text { loadings }\end{array}$} & \multicolumn{3}{|c|}{\begin{tabular}{|r|} 
Parameter \\
\end{tabular}} \\
\hline & & & \begin{tabular}{|l|} 
Standard \\
error $(S E)$
\end{tabular} & $\begin{array}{l}\text { Critical } \\
\text { ratio (CR) }\end{array}$ & $\mathrm{SMC}$ \\
\hline & Using evaluation tools: V5 & 0.783 & - & - & 0.613 \\
\hline & Using interaction tools: V4 & 0.813 & 0.076 & 11.861 & 0.661 \\
\hline & Use of course topics: V2 & 0.617 & 0.076 & 9.007 & 0.381 \\
\hline & CGP & 0.983 & - & - & 0.967 \\
\hline & ACGP & 0.949 & 0.032 & 28.893 & 0.900 \\
\hline & Content interaction: SC_CONTE & 0.733 & 0.038 & 12.794 & 0.537 \\
\hline & Links to content: SC_LINKS & 0.608 & 0.020 & 9.973 & 0.369 \\
\hline & Grades: SC_GRADE & 0.852 & 0.040 & 16.094 & 0.726 \\
\hline & Drop box: SI_DROP & 0.822 & 0.061 & 15.196 & 0.675 \\
\hline & Groups: SS_GROUP & 0.728 & 0.035 & 12.687 & 0.530 \\
\hline & Discussion board: SS_DISCU & 0.491 & 0.023 & 7.722 & 0.242 \\
\hline & Collaboration:SI_COLLA & 0.842 & - & - & 0.710 \\
\hline Measurement & e4 & 0.201 & 0.026 & 7.633 & \\
\hline error variances & e3 & 0.133 & 0.019 & 6.911 & \\
\hline & e1 & 0.245 & 0.026 & 9.571 & \\
\hline & e6 & 0.029 & 0.021 & 1.404 & \\
\hline & e7 & 0.079 & 0.019 & 4.217 & \\
\hline & e11 & 0.409 & 0.042 & 9.750 & \\
\hline & e12 & 0.141 & 0.014 & 10.233 & \\
\hline & e13 & 0.318 & 0.037 & 8.481 & \\
\hline & e14 & 0.822 & 0.092 & 8.963 & \\
\hline & e15 & 0.354 & 0.036 & 9.774 & \\
\hline & e16 & 0.190 & 0.018 & 10.458 & \\
\hline & e17 & 0.811 & 0.094 & 8.652 & \\
\hline Disturbance & e19 & 0.623 & 0.119 & 5.244 & \\
\hline error variances & e18 & 0.368 & 0.043 & 8.482 & \\
\hline Direct effect & IT self efficacy $\rightarrow$ e-learning interactions & 0.828 & & 9.693 & \\
\hline & $\begin{array}{l}\text { e-learning interactions } \rightarrow \text { academic } \\
\text { achievement }\end{array}$ & 0.756 & & 11.204 & \\
\hline Indirect effect & $\begin{array}{l}\text { IT Self efficacy } \rightarrow \text { e-learning interaction } \\
\rightarrow \text { achievement }\end{array}$ & 0.55 & & & \\
\hline
\end{tabular}

Note: V2, V4.V5 = IT self-efficacy indicators. SC = student-content, SS = student-student, $\mathrm{SI}=$ student-instructor. SMC = squared multiple correlations. All the underlined items were constrained to 1.00 and not tested for statistical significance $\mathrm{p}<0.01$ for all un-standardised estimates.

\section{E-learning interactions and students' academic achievement}

In the present study, e-learning interaction activities significantly predicted students' academic achievement. The e-learning interaction activities factor was determined by interaction between students and content, student and student, and lastly students and instructor. This supported the ideas of Moore (1989) who outlined three types of interactions crucial for e-learning activities. When the students were involved in these three interactions, they were able to do well in their final exams. These findings have further proven empirically that the e-learning interaction activities could support or enhance students' academic achievement as suggested by Alsharif (2006), Miller (1994), and Milman and Heineck (1999). 
A meta-analysis research by Zhao, et al. (2005) found that the instructor's involvement was the most significant factor in interactions between the teacher and students. However, the present research indicates that student-content interaction makes the highest contribution to the e-learning interactions. Student-student interaction was the lowest predictor for e-learning interaction activities. This may explain why students preferred to utilise the content for their source of learning. These findings do not concur with Su, Bonk, Magjuka, Liu \& Lee (2005) who found that the interactions of student-instructor and student-student were the leading factors for a successful online education. It can be suggested that the students did not utilise the collaboration tools of the Blackboard system fully. This could result from a preference for meeting face to face rather than virtually. Furthermore, they also prefer to interact with the instructor and content due to the influence of the 'exam culture'.

The use of e-learning interactions, specifically student-content, has been popular due to an emphasis by instructors upon producing value-added content (Muilenburg et al., 2005). There may be an indication that UOS has well-prepared curriculum and instructional designs for e-learning programs. Thus, it attracted students to make good use of the e-learning content, proving that e-learning courses have achieved one goal in e-learning implementation. Instructor behaviours have played a key role in making e-learning effective. This finding showed that students did interact with their instructors in order to get valuable feedback, assistance and encouragement. Despite the argument which postulated changes in teachers' roles from 'centre stage' to 'guide on the side' (Gibson, 2002), the present findings have shown a significant and important role of the instructors and the students. In the constructivist learning environment, this concept has already been proposed by Marks (2000).

\section{IT self-efficacy and academic achievement via e-learning interaction}

The direct relationship between students' IT self-efficacy and students' academic achievement was not prevalent in this present study. This has contradicted with previous research findings with regards to the direct relation between students' IT selfefficacy and students' academic achievement (Bates, 2006; Gaythwaite, 2006; and Johnson et al., 2000). Although these researchers have suggested that students' IT selfefficacy is a strong predictor of students' academic achievement, this study suggests that students' IT self-efficacy is a relatively weak factor. This could be due to the students' reluctance to reveal frankly their IT self-efficacy for this study, being reluctant to show their own weakness in order to stay on par with other students. However, there was also strong indication that possessing IT self-efficacy alone will not necessarily lead to academic achievement. To achieve good grades in an e-learning environment requires collaborative learning and specific involvement in the interactions. These interactions, namely student-student, student-instructor and student-content, could become strong predictors of students' academic achievement. The findings in this study agree with findings by DeTure (2004), which indicated that students' IT self-efficacy was a poor predictor of their success in online courses.

In IT self-efficacy, students perceived themselves as having the skills to seek course topics from the Blackboard learning system. They have also revealed that they have the skills to use the interaction and evaluation tools in Blackboard. The findings of the students' IT self-efficacy variable were explained by the three items factors V2 = use of course topics; V4 = using interaction tools and V5 = using evaluation tools. These three skills were utilised in the e-learning environment. As a result, students achieved good grades in their examination. 
Instructors should provide a meaningful and well-designed program to encourage positive feedback throughout the course. Based on their students' perceived IT selfefficacy, lecturers can assist students to perform at a higher level, minimise withdrawal and dropout rates from e-learning courses, and increase the overall level of satisfaction with an e-learning environment. This recommendation is in line with findings by Shih, Martinez-Molina and Muñoz (2008). Moreover, instructors may design special activities to elevate student-student interaction, noting that social interaction is among the skills needed to increase both performance and productivity.

The findings of the present study provid several implications for the e-learning environment. One major finding from the current study is that student-content interaction was the highest factor predictor of students' academic achievement at UOS. This implies that a higher level of understanding of the e-learning interactions factors was crucial to understanding students' behaviour within the e-learning environment, and the patterns of interactions which could promote students' academic achievement levels. Educators, instructional designers and instructors should take this into consideration when designing e-courses, with more activities requiring interaction being included within their courses. Furthermore, educators should assess students' IT self-efficacy before engaging them in the e-learning environments. By providing remedial procedures for students with low IT self-efficacy, UOS authorities will benefit from the present study.

Additionally, instructors should provide a meaningful and well-designed program to encourage positive feedback throughout the course. Based on their students' perceived IT self-efficacy, lecturers can assist students to perform at a higher level and to minimise the withdrawal and dropout rates from e-learning courses as well as increase the overall level of satisfaction attained in an e-learning environment. This recommendation is similat to that by Shih, Martinez-Molina and Muñoz (2008). Moreover, instructors may design special activities to enhance student-student interaction, as social interaction is among the skills needed by graduates.

\section{Recommendations}

Further research studies should examine why students at UOS still do not favour peer interactions and why content interaction is a stronger factor. Also, further research studies should be carried out with other students in different countries in order to better understand the nature of both IT self-efficacy and e-learning interactions in other educational contexts. As IT self-efficacy is a subject specific construct, further research studies may attempt to improve the scale by adding more in-depth items, applying it to other student samples and different levels of education. Considering Web 2.0 applications, a longitudinal study could be carried out to identify a Web 2.0 self-efficacy scale which merges, social networks with learning activities within the elearning environment.

A qualitative study of the content of communication tools will give educators a better understanding of what factors could influence students' communication ability with instructors, students and the content. Such studies will help instructional designers improve e-learning modules to meet the needs of the new technology era. Designing training introductory course materials, based on the four factors affecting students' IT self-efficacy, i.e. performance accomplishment, vicarious experiences, verbal persuasion, and physiological states as suggested by Bandura (1997) needs to be done to cater for students with problematic IT self-efficacy. 
Instructors' engagement with e-learning has been less enthusiastic than expected. More investigations of the barriers that prevent lecturers from deploying new technology in their classrooms should be carried out, as the cost of implementing an elearning system from an actual effective use perspective may be expensive if lecturers remain reluctant to fully utilise the system and its advanced tools in their courses. Scholar is a tool that enables students and instructors to save and classify web based bookmarks and searches, share resources among students and instructors within the institution and with other institutions, automatically update courses with dynamic content feeds, and enable student contributions to course collections. Wimba Voice, a set of online voice recording tools can be integrated within the Blackboard system to record voice and attach it to an email to send to Blackboard instructors or students (voice mail), create a vocal discussion board to post and reply to threaded voice recordings (voice board) and specify a series of web pages and record a voiceover to go along with each webpage (voice presentation); again this tool has been neglected by the Blackboard system users.

\section{References}

Alsharif, N. Z. (2006). Optimizing the four important interactions in distance education: An example medicinal chemistry course. Paper presented at the Annual Meeting of the American Association of Colleges of Pharmacy, Sheraton San Diego Hotel \& Marina, San Diego, California, USA, 5 July [viewed 11 Oct 2006, verified 6 Sep 2011]. http: / / www.allacademic.com/meta/p115685_index.html

Bandura, A. (1977). Self-efficacy: Toward a unifying theory of behavioral change. Psychological Review, 84, 191-215. http:/ / doi.apa.org/journals/rev/84/2/191.pdf

Bates, C. H. (2006). The effects of self-regulated learning strategies on achievement, control beliefs about learning, and intrinsic goal orientation. Dissertation Abstracts International, 67(5). (UMI No. 3218874). http: / / gradworks.umi.com/32/18/3218874.html

Benbunan-Fich, R. (2002). Improving education and training with information technology. Communications of the ACM, 45(6), 94-99. http: / / dx.doi.org/10.1145/508448.508454

Blackboard System Manual (2007). Blackboard Inc. [viewed 2 Feb 2007]. http: / / www.blackboard.com/

Su, B., Bonk, C. J., Magjuka, R. J., Liu, X. \& Lee, S.-H. (2005). The importance of interaction in web-based education: A program-level case study of online MBA courses. Journal of Interactive Online Learning, 4(1). [viewed 20 Mar 2007]. http:/ / www.ncolr.org/jiol/issues/pdf/4.1.1.pdf

Burkhardt, M. \& Brass, D. (1990). Changing patterns of patterns of change: The effects of a change in technology on social network structure and power. Administrative Science Quarterly, 35(1), 104-127.

DeTure, M. (2004). Cognitive style and self-efficacy: Predicting student success in online distance education. American Journal of Distance Education, 18(1), 21-38. [abstract only] http:/ / www.ajde.com/Abstracts/abs18_1b.htm

Devries, Y. E. (1996). The interactivity component of distance learning implemented in an art studio class. Education, 117(2), 180-184.

Devries, P. (2005). An analysis framework approach for managing corporate e-learning. eJOV, 7, 112-118. [viewed 6 Jan2007; abstract only]. http: / / www.ejov.org/apps / pub.asp?Q=1643\&T=eJOV\%20Issues 
Garrison, D. R. \& Anderson, T. (2003). E-learning in the 21st century: A framework for research and practice. New York: Falmer Press.

Gaythwaite, E. S. (2006). Metacognitive self-regulation, self-efficacy for learning and performance, and critical thinking as predictors of academic success and course retention among community college students enrolled in online, telecourse, and traditional public speaking courses. Dissertation Abstracts International, 67(3). (UMI No.3210356). [abstract only] http: / / sunzi.lib.hku.hk/ER/detail/hkul/3840132

Gibson, C.A. (2002). Being real: The student-teacher relationship and African-American male delinquency. New York: LFB Scholarly Publishing.

Gunawardena, C., Lowe, C. A. \& Anderson, T. (1997). Analysis of a global online debate and the development of an interaction analysis model for examining social construction of knowledge in computer conference. Journal of Educational Computing Research, 17(4), 397-431. [viewed 22 Jan 2008]. http:/ / dx.doi.org/10.2190/7MQV-X9UJ-C7Q3-NRAG

Harmon, S. W. \& Jones, M. G. (1999). The five levels of web use in education: Factors to consider in planning online courses. Educational Technology, 39(6), 28-32.

Hillman, D. C. A., Willis, D. J., \& Gunawerdena, C. N. (1994). Learner-interface interaction in distance education: An extension of contemporary models and strategies for practitioners. The American Journal of Distance Education, 8(2), 30-42. http: / / dx.doi.org/10.1080/08923649409526853

Johnson, R. D. \& Marakas, G. M. (2000). The role of behavioral modeling in computer skills acquisition: Toward refinement of the model. Information Systems Research, 11(4), 402-417. http: / / dx.doi.org/10.1287/ isre.11.4.402.11869

Lee, C.-Y. C.(undated). Self-efficacy instrument. http:/ / pegasus.cc.ucf.edu/ coreylee/ projects / self_efficacy_instrument.htm

Marakas, G. M., Johnson, R. D. \& Clay, P. F. (2007). The evolving nature of the computer selfefficacy construct: An empirical investigation of measurement construction, validity, reliability and stability over time. Journal of the Association for Information Systems, 8(1), 16-46. http: / / aisel.aisnet.org/jais/vol8/iss1/2/

Marks, H. M. (2000). Student engagement in instructional activity: Patterns in the elementary, middle, and high school years. American Educational Research Journal, 37(1), 153-184. http: / / dx.doi.org/10.3102/00028312037001153

Miller, I. (1994). KidVid: Math games by kids for kids. A SBIR proposal to the Department of Energy by The Lightspan Partnership, Inc., Carlsbad, CA.

Milman, N. \& Heinecke, W. (1999). Technology and constructivist teaching in post-secondary instruction: Using the World Wide Web in an undergraduate history course. [viewed 6 May 2007, verified 7 Sep 2011]. http:/ / www.vcdh.virginia.edu/milman_heinecke.html

Miltiadou, M. \& Yu, C. H. (2000). Validation of the Online Technologies Self-efficacy Scale (OTSES). http: / / www.eric.ed.gov/ERICWebPortal/ contentdelivery/ servlet/ ERICServlet? accno $=\mathrm{ED} 445672$

Moore, M. (1989). Three types of interactions. The American Journal of Distance Education, 3(2), 1-7. Retrieved February 5, 2006. http:/ / www.ajde.com/Contents/vol3_2.htm

Muilenburg, L. Y. \& Berge, Z. L. (2005). Student barriers to online learning: A factor analytic study. Distance Education, 26(1), 29-48. http: / / dx.doi.org/10.1080/01587910500081269 
Ryan, S., Scott, B., Freeman, H. \& Patel, D. (2000). The virtual university: The Internet and resourcebased learning. London: Kogan Page.

Shih, P., Martinez-Molina, A. \& Muñoz, D. (2008). The navigation experience in an online activity: Related variables to user satisfaction. Proceedings of World Conference on Educational Multimedia, Hypermedia and Telecommunications, 1484-1493. Chesapeake, VA: AACE. Retrieved January 1, 2009. http:/ / www.editlib.org/p/28577

Sutton, L. (2001). The principle of vicarious interaction in computer-mediated communications. International Journal of Educational Telecommunications, 7(3), 223-242. http:// www.editlib.org/p/9534

Wagner, E. D. (1994). In support of a functional definition of interaction. American Journal of Distance Education, 8(2), 6-29. http: / / dx.doi.org/10.1080/ 08923649409526852

Webster, J. \& Martocchio, J. J. (1992). Microcomputer playfulness: Development of a measure with workplace implications. MIS Quarterly, 16(2), 201-226. http: / / www.jstor.org/ stable/249576

Zhao, Y., Lei, J., Yan, B., Lai, C. \& Tan, S. (2005). What makes the difference? A practical analysis of research on the effectiveness of distance education. Teachers College Record, 107(8), 18361884. http: / / www.tcrecord.org/ Content.asp?ContentId=12098

Authors: Dr Enas Abulibdeh, Assistant Professor, College of Education, Al Ain University of Science and Technology, United Arab Emirates

Email: enas220@gmail.com, enas.abulibdeh@aau.ac.ae

The researcher is currently working as assistant professor at Al Ain University in UAE. With a PhD in instructional technology, she is teaching instructional technology, Internet applications and practicum, IT teaching methods for diploma and undergraduate students. She is interested in faculty professional development, Web 2.0, social media, cloud computing, and quality of e-learning.

Sharifah Sariah Syed Hassan, International Islamic University Malaysia, PO Box 10, 50728 Kuala Lumpur. Email: sariah1199@yahoo.com Web: http: / / www.iium.edu.my/ The researcher is now teaching at International Islamic University Malaysia. Subjects involved are instructional technology, Internet applications in education, and structural equation modelling.

Please cite as: Abulibdeh, E. S. \& Syed Hassan, S. S. (2011). E-learning interactions, information technology self efficacy and student achievement at the University of Sharjah, UAE. Australasian Journal of Educational Technology, 27(6), 1014-1025. http:/ / www.ascilite.org.au/ajet/ajet27/abulibdeh.html 